\title{
Performance Appraisal An Outcome Of Performance Contracting In Insurance Firms In Kenya Nairobi County
}

\author{
Dr.Tabitha Murerwa, Dr. Susan Nzioki and Dr.Wilson Muema \\ DOI: 10.29322/IJSRP.10.08.2020.p104109 \\ http://dx.doi.org/10.29322/IJSRP.10.08.2020.p104109
}

\begin{abstract}
Through performance appraisal an organization undertakes to measure the set goals against employee actual performance with respect to the period in question. It is also used to identify an employee's weaknesses and strengths and provide for appropriate adjustments. This study examined the importance of performance appraisal as an outcome of performance contracting in insurance firms in Kenya. The study employed a descriptive approach for and used a population that consisted of 49 heads of performance contracting sections of 49 Kenyan insurance firms. A census method of sampling was used due to the availability of the population._A standardized questionnaire was used as main data collection instrument. The Statistical Package for Social Sciences (SPSS, version 24) analyzed the quantitative statistics and generate descriptive statistics. using the Using tables and figures for presentation, the study found that; performance appraisal affects employee performance among insurance firms in Kenya. The study findings revealed that there was effective performance appraisal procedures and methods in place that were used by the management in insurance firms in Kenya. The study recommends that; insurance firms in Kenya in collaboration with the IRA should structure and review their performance appraisal policy to include their support employee
\end{abstract}

Index Terms- Organizational Performance, Performance Appraisal, Performance Appraisal Methods, insurance firms

\section{INTRODUCTION}

$\mathrm{T}$ oday's organizations seem to change much more rapidly than in the past because of increased competition and the everchanging business environment. This explains why organizations require managing and improving their performance through performance contracting so as to be competitive. Lardi (2008), defines a performance contract as written agreement between a government or its affiliated organization and the management of public enterprises. It contains specific measurable objectives for a period and when the period lapses, the overall performance is examined using the set objectives. (World Bank, 2018). Performance contracting has been regarded as an effective measure of enhancing performance in organization as well as governmental agencies. (Prajapati, 2010).

The objective of introducing performance contracts was to advance on quality delivery and services through better performance by making managers accountable for results; maximize national resources through enhanced performance; reduce dependency on the national treasury; effective resource usage by incorporating a culture of accountability and transparency, improve effectiveness and ensure that public resources were used on attaining national goals set out and reduced misunderstanding resulting from multiplicity of objectives (Boyne, 2015). The major contribution of performance contracting is that it focuses on attaining results - competitive products and services for customers inside and outside the organization. Opiyo (2006) notes that performance contracting has facilitated managers to have a positive attitude towards their staff and it has encouraged innovation, improved service delivery, better customer service, efficient resource utilization and performance centered culture in the public service. (Prajapati, 2010)

Performance contracts specify acceptable standards of performance or measurable targets which the insurance firms require its employees to attain in a given period. (insurance industry annual report, 2018).

Performance contracting from a Kenyan perspective designed by blending global best practices as well as borrowing from the Balanced Score Card. It also provides linkages between strategic objective, long term goals and the annually set budgets (GoK, 2010). PC in Kenya was first witnessed in government agencies in the management of state corporations in 1989 as a way of improving service delivery. The emergence of signing performance contracts between the Kenyan government and other agencies began in April 1989. The Kenya Railways Corporation signed the first contract. It was followed suit by the National Cereals Board (Kobia\& Mohamed, 2006). The Cabinet Memorandum No. 90 of 1990 paved the way for PC in public institutions (Murui \& Orwa, 2013). The Public Sector Reforms of 1993 by the Kenyan government rationalized and contained the public service resulted in a colossal job loss for employees in job group A-G. (Opiyo, 2006).

\section{PAST STUDIES}

Performance Appraisal (PA)is a formal process of reviewing and evaluating employee performance and providing a corrective action if targets are not met or giving a credit of work well done (Make staff Review Count, 2009). The aims of PA are; organizational goal alignment, manager-employee communication, employee development, effective personnel administration Organizations goal alignment is the ultimate objective of a performance management process where individual performance is aligned with organizational performance argues that the goal of alignment process is to create a result-oriented 
culture which is a significant benefit of the performance appraisal exercise. According to argue that manager-employee communication is the rapport between employees and management about the feedback on organizational activities, events and performance towards organizational goals and objectives.

In a study on examining the transformation of the public service with regards to performance contracting Wanyama (2013) examined performance management in public institutions in Kenya. The study sought to examine whether performance contracting had an effect on government institutions in Kenya. From its onset, the study examined the efficiency and efficacy. Other areas examined were transparency and accountability of. Resources. Mbua and Sarisar (2013) when exploring the challenges witnessed when implementing PC in the Kenyan public sector. The study established that several challenges face PC and the sustainability of performance gains remains a key issue. Public Contracting must strive to improve public sector delivery while at the same time addressing the challenges observed. Gakure, Muriu and Orwa (2013) examined the effect of PC on different departments in civil service performance in Kenya. through a proportionate sample of 108 respondents out of a possible 1072, the study results were analyzed and the correlations showed there is a strong relationship between performance contracting and performance effectiveness. The variance also revealed that performance contracting is significant on performance. The regression model shows that an increase in performance contracting increased in performance effectiveness. The study results show the effort the government is making in performance contracting in terms of effort and cost. It is concluded from the findings that performance contracting leads to effectiveness of performance. When it comes to Performance Contract on Organization Performance, Letangule, and Letting's (2012) study revealed the performance contracting affected delivery of service the overall service quality and employee creativity. On examining the influencing factors of PC in Kenya, Gathai, Ngugi, Waithaka and Kamingi (2012) examining employees of Kenya Civil Authority, examined contracts signed between 2009 and 2012. The results show that the targets achieved were in tandem with the organizations objectives. Akaranga's(2008), study reveals that all government parastatals and agencies had put performance contracting in place. The study results show that there was an improvement in incomes as well as the delivery of service by the said agencies. The financial year results for the year ending 2005/6 also show that revenue exceeded expenditure. Performance contracting can be detrimental when too much focus is given to targets and how they can be achieved. It is even more disadvantageous when the said targets are not in tandem with the expected outcomes. (Keelaar,2007). Kobia and Mohammed (2006) examined the challenges and successes that have been noted as a result of performance contracting. In their survey among civil servants, 280 respondents who consisted mainly of senior employees of the civil service noted that they did not have an understanding or the use of performance contracting at the organization level. The employees were stationed at the Kenya Institute of Administration. The results show that while PC had been implemented, there was little effort to make the employees know about it or its potential benefits.
In their study Marjorie et al (2006) identified the following as challenges of the process of appraisal. They are viz. increased red tape; little commitment; uncertainty when seeking areas for development and the rewarding process; and bias in judgment. Little devotion on the side of the government to the promised incentives was ranked highest by respondents. Similarly, Shirley et al (2001) ranked lack of commitment as the highest challenge in China. Bias in judgment was ranked second with a significant difference of $5 \%$ level of significance between high management and subordinates.

\section{METHODOLOGY}

\section{A Research Design}

This study adopted a descriptive research design. According to Kothari (2012 it is a systematic technique used to observe and describe the comportment of a matter without any influence. Descriptive research design is a design that is suitably used when explaining a phenomenon (for describing a situation and especially the manner in which independent variables influence the dependent variable). Notably the present study described the manner in which performance contracting is linked to employee performance in insurance firms in Kenya, rendering descriptive research design ideal for it (Gupta \& Rangi, 2014).

\section{B Target Population}

The target population is defined as entire group of individuals or objects possessing same observable characteristics and from where the findings can be generalized (Mugenda \& Mugenda, 2003). Insurance Regulatory Authority [IRA] (2018) indicates that there are 49 Registered Insurance firms in Kenya. So, in this study, the target population consisted of 49 heads of performance contracting sections of 49 insurance firms in Kenya as captured in the sampling frame (see appendix III). This population was chosen because they were the implementers of the performance contracting in insurance firms in Kenya. So, the respondents to the study were the heads of performance contracting sections of the insurance firms in Kenya while the unit of analysis was the insurance companies.

\section{RESULTS AND DISCUSIONS}

\section{Demographic information}

The study found that $14(34.15 \%)$ of the respondents were 51 years and above as $12(29.27 \%)$ of the respondents were between 41 and 50 years while $15(36.59 \%)$ of the respondents were between 31 and 40 years. Majority of the respondents 23 $(56.10 \%)$ had worked for a period between 16 years and above, 1 $6(39.02 \%$ of the respondents had worked for a period of 6-10 years, while $2(4.88 \%)$ of the respondents had worked for a period of between 11 and 15 years as shown on figure 4.4. These results implies that majority of the employees of insurance companies at the management level have had over 6 years of work experience.

\section{Descriptive Analysis}

Using quantitative analysis, the study yielded descriptive statistics showing the properties of the study variables when assessing the study objective as well as the manner in which the 
variables affected each other and especially the independent and dependent variables. The results were just direct answers to the questions in the tool which were presented using percentages, frequencies, means and standard deviations

\section{Performance Appraisal and Employee Performance}

The study assessed the first objective to establish the importance of performance appraisal on employee performance in insurance firms in Kenya by first seeking to establish the level of goal setting at every performance appraisal. According to the results, $154(82.93 \%)$ of the respondents agreed that they set goals at every performance appraisal, while $34(17.07 \%)$ of the respondents disagreed that they did not set goals at every performance appraisal as shown on figure 4.5. The findings are consistent with (Lorsch, 2002), who found out that, unless the supervisors do the appraising themselves, they cannot adequately discharge their responsibilities of assisting and training the subordinates.

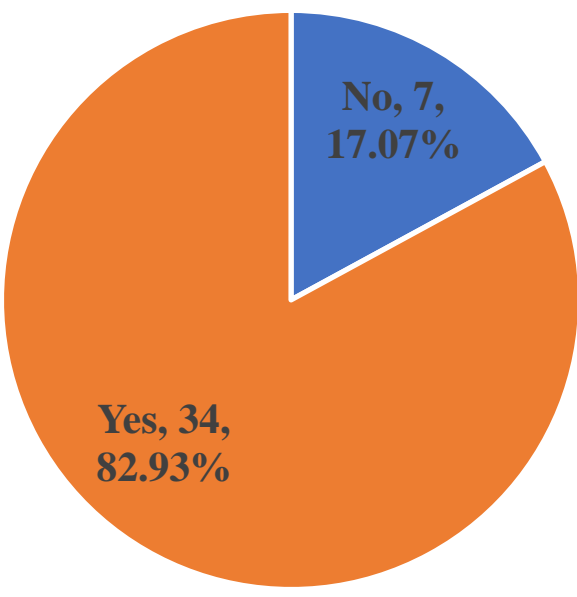

Figure 4.1: Goal Setting

Performance appraisal was used as one of the factors that affect employee performance of insurance firms in Kenya. The respondents were therefore required to rate their responses on a 5point Likert scale of 1-5; $5=$ Strongly Agree;4= Agree; $3=$ Neutral;
$2=$ Disagree; $1=$ Strongly Disagree as shown on Table 4.2. on average, they strongly agreed that the performance appraisal was high $(\mathrm{M}=4.35 ; \mathrm{SD}=0.88)$.

Table 4.1: Performance Appraisal

\begin{tabular}{|c|c|c|c|c|c|c|c|c|c|c|}
\hline & \multicolumn{2}{|c|}{$\begin{array}{l}\text { Strongly } \\
\text { Disagree }\end{array}$} & \multicolumn{2}{|c|}{ Disagree } & \multicolumn{2}{|c|}{ Neutral } & \multicolumn{2}{|c|}{ Agree } & \multicolumn{2}{|c|}{ Strongly Agree } \\
\hline & $\mathrm{N}$ & $\%$ & $\mathrm{~N}$ & $\%$ & $\mathrm{~N}$ & $\%$ & $\mathrm{~N}$ & $\%$ & $\mathrm{~N}$ & $\%$ \\
\hline $\begin{array}{l}\text { My appraiser helps me to understand } \\
\text { the process used to evaluate and rate } \\
\text { my Performance }\end{array}$ & 0 & $0.00 \%$ & 0 & $0.00 \%$ & 7 & $17.07 \%$ & 22 & $53.66 \%$ & 12 & $29.27 \%$ \\
\hline $\begin{array}{l}\text { The performance appraisal review } \\
\text { discussion is the only time I get } \\
\text { feedback about my performance }\end{array}$ & 0 & $0.00 \%$ & 1 & $2.44 \%$ & 2 & $4.88 \%$ & 25 & $60.98 \%$ & 13 & $31.71 \%$ \\
\hline $\begin{array}{l}\text { Employees are provided with } \\
\text { feedbacks to help improve their } \\
\text { performance }\end{array}$ & 0 & $0.00 \%$ & 3 & $7.32 \%$ & 8 & $19.51 \%$ & 23 & $56.10 \%$ & 7 & $17.07 \%$ \\
\hline
\end{tabular}

The results show that the majority of the respondents forming $22(53.66 \%)$ agreed that the appraisers helped the employees to understand the process used to evaluate and rate their performance. Meanwhile a majority of $25(60.98 \%)$ of the respondents agreed that performance review discussion is the only time they get feedback about their performance while a majority of $23(56.10 \%)$ of the respondents agreed that they were provided with feedback to help them improve their performance. The results showed that the they set goals at every performance appraisal.
These results show that there was high appreciation of performance appraisal among insurance companies in Kenya where they had appraisers who were helping the employees to understand the process used to evaluate and rate their performance while they used performance review discussion is the only time they get feedback about the employee performance. according to these results, the performance appraisal exercise ensured employees were provided with feedback to help them improve their performance. Various empirical literature has associated 
performance appraisal with employee performance with most of the studies showing that performance appraisal affects employee performance as confirmed in this study. In the study by Gakure et al. (2013), it was revealed that performance contracting significantly affects performance while in their Letangule, and Letting (2012) revealed that performance contracting affected service quality, efficiency, and consistency and employee creativity at the ministry of education to a great extent. Although In their study Marjorie et al (2006) identified challenges of the process of appraisal as lack of commitment; tension about identifying development needs and allocation of rewards, Gathai et al. (2012) concluded that performance measurements are used to evaluate, control and improve operations process for ensure achievement of organizational goals and objectives.

\section{Inferential Analysis}

Performance appraisal and employee performance in insurance firms in Kenya

The study tested the null hypothesis

$\mathrm{H}_{01}$ : Performance appraisal has no significant effect on employee performance in insurance firms in Kenya

To produce the results in Table 4.7

Table 1: Analysis by Responses against predicted responses

\begin{tabular}{llll}
\hline Predicted responses categories & & Count & \% within \\
\hline $\begin{array}{l}\text { My appraiser helps me to understand the } \\
\text { process used to evaluate and rate my }\end{array}$ & $\begin{array}{l}\text { Agree } \\
\text { Performance }\end{array}$ & 22 & $17.07 \%$ \\
& Strongly Agree & 12 & $53.66 \%$ \\
& & & $29.27 \%$ \\
$\begin{array}{l}\text { The performance appraisal review discussion is } \\
\text { the Disagree }\end{array}$ & 1 & $2.44 \%$ \\
performance & Neutral & 2 & $4.88 \%$ \\
& Agree & 25 & $60.98 \%$ \\
& Strongly Agree & 13 & $31.71 \%$ \\
$\begin{array}{l}\text { Employees are provided with feedbacks to help } \\
\text { improve their performance }\end{array}$ & Disagree & 3 & $7.32 \%$ \\
& Neutral & 8 & $19.51 \%$ \\
& Agree & 23 & $56.10 \%$ \\
Total & Strongly Agree & 7 & $17.07 \%$ \\
\hline
\end{tabular}

According to these results, the model seems to be doing good of predicting outcome categories, for "My appraiser helps me to understand the process used to evaluate and rate my Performance (agree)" the models correctly classifies 53.66\%, "the performance appraisal review discussion is the only time I get feedback about my performance (agree)" classifies 60.98\%, and Employees are provided with feedbacks to help improve their performance (neural) classifies $56.10 \%$.

The regression results are captured in table 4.8

Table 2: Logistic Results for Performance appraisal and Service delivery

\begin{tabular}{llllll}
\hline Model Fitting Information & & & & \\
Model & $\begin{array}{l}-2 \\
\text { Likelihood }\end{array}$ & $\begin{array}{l}\text { Logi- } \\
\text { Square }\end{array}$ & df & Sig. \\
Intercept Only & 62.807 & & & \\
Final & 59.195 & 3.612 & 8 & 0.890 \\
Goodness-of-Fit & & & & & \\
& Chi-Square & df & Sig. & \\
Pearson & 50.253 & 43 & 0.208 & \\
Deviance & 42.271 & 43 & 0.503 &
\end{tabular}




\section{Pseudo R-Square}

Cox and Snell

0.084

Nagelkerke

0.094

McFadden

0.039

Test of Parallel Lines

Model

Null Hypothesis

-2 Log Chi- df Sig.

General

Likelihood
59.195

General

$.000 b$

$59.195 \quad 16$

0.000

\section{Explanatory variables associated with high level of Service delivery}

\begin{tabular}{lll} 
Item name & $\begin{array}{l}\text { Regression } \\
\text { coefficient }\end{array}$ & p-value \\
$\begin{array}{l}\text { My appraiser helps me to understand the process used } \\
\text { to evaluate and rate my Performance }\end{array}$ & 0.566 \\
$\begin{array}{l}\text { The performance appraisal review discussion is the } \\
\text { only time I get feedback about my performance }\end{array}$ & 0.15 & 0.725 \\
$\begin{array}{l}\text { Employees are provided with feedbacks to help } \\
\text { improve their performance }\end{array}$ & -0.003 & 0.996 \\
\hline
\end{tabular}

The model fitting information show the p-value was 0.890 indicating that there is no significant reduction in the chi-square statistics ( $p>.005)$. The chi-square statistic (3.612) indicates that the model does not give a significant improvement over the baseline intercept-only model, implying that the model does not give better predictions than just guessing based on the marginal probabilities for the outcome categories.

The Goodness-of-Fit, which contains Pearson's chi-square statistic for the model and chi-square statistic based on the deviance for testing inconsistencies of observed data with the fitted model, shows that these statistics not significant. However, they are large enough to conclude that the data and the model predictions are similar. So, the model is a good one. The
Nagelkerke $\mathrm{R}^{2}$ (0.094) indicates the model can account for $9.4 \%$ of the variance in service delivery. The test of parallel lines rejects the null hypothesis of the assumption that across response categories". So, the model does not fit the data well since the observed significant level is very small.

These results show that :"my appraiser helps me to understand the process used to evaluate and rate my Performance" (p-value $=0.566$ ), "the performance appraisal review discussion is the only time I get feedback about my performance ( $\mathrm{p}$-value = 0.725 ), "employees are provided with feedbacks to help improve their performance" ( $\mathrm{p}$-value $=0.996)$ are not significant with service delivery.

\section{Table 3: Logistic Results for Performance appraisal and Employees motivation}

\begin{tabular}{|c|c|c|c|c|}
\hline \multicolumn{5}{|c|}{ Model Fitting Information } \\
\hline Model & $-2 \quad \log$ & Chi- & df & Sig. \\
\hline Intercept Only & $\begin{array}{l}\text { Likelihood } \\
64.321\end{array}$ & Square & & \\
\hline Final & 58.423 & 5.897 & 8 & 0.659 \\
\hline \multicolumn{5}{|c|}{ Link function: Negative Log-log. } \\
\hline & Chi-Square & Df & Sig. & \\
\hline Pearson & 37.320 & 60 & 0.991 & \\
\hline Deviance & 38.023 & 60 & 0.988 & \\
\hline \multicolumn{5}{|c|}{ Pseudo R-Square } \\
\hline Cox and Snell & 0.134 & & & \\
\hline Nagelkerke & 0.147 & & & \\
\hline
\end{tabular}


McFadden

0.059

Test of Parallel Linesa

Model

Intercept Only

Final

\section{Explanatory variables associated with high level of employee's motivation}

\begin{tabular}{|c|c|c|}
\hline $\begin{array}{l}-2 \quad \text { Log } \\
\text { Likelihood } \\
75.514\end{array}$ & $\begin{array}{l}\text { Chi- } \\
\text { Square }\end{array}$ & $\mathrm{df}$ \\
\hline 67.350 & 8.163 & 8 \\
\hline
\end{tabular}

\begin{tabular}{lll} 
Item name & $\begin{array}{l}\text { Regression } \\
\text { coefficient }\end{array}$ & p-value \\
$\begin{array}{l}\text { My appraiser helps me to understand the process } \\
\text { used to evaluate and rate my Performance }\end{array}$ & -0.112 & 0.802 \\
$\begin{array}{l}\text { The performance appraisal review discussion is } \\
\text { the only time I get feedback about my }\end{array}$ & 0.444 & 0.280 \\
performance & & \\
$\begin{array}{l}\text { Employees are provided with feedbacks to help } \\
\text { improve their performance }\end{array}$ & -0.882 & 0.117 \\
\hline
\end{tabular}

The model fitting information show the p-value was 0.659 indicating that there is no significant reduction in the chi-square statistics ( $p>.005)$. The chi-square statistic (5.897) indicates that the model does not give a significant improvement over the baseline intercept-only model, implying that the model does not give better predictions than just guessing based on the marginal probabilities for the outcome categories.

The Goodness-of-Fit, which contains Pearson's chi-square statistic for the model and chi-square statistic based on the deviance for testing inconsistencies of observed data with the fitted model, shows that these statistics not significant. However, they are large enough to conclude that the data and the model predictions are similar. So, the model is a good one. The
Nagelkerke $\mathrm{R}^{2}(0.149)$ indicates the model can account for $14.90 \%$ of the variance in service delivery. The test of parallel lines accepts the null hypothesis of the assumption that across response categories". So, the model fits the data well since the observed significant level is large.

These results show that :"my appraiser helps me to understand the process used to evaluate and rate my Performance" ( $\mathrm{p}$-value $=0.802)$, "the performance appraisal review discussion is the only time I get feedback about my performance (p-value = 0.280 ), "employees are provided with feedbacks to help improve their performance" ( $\mathrm{p}$-value $=0.117)$ are not significant with employees motivation.

Table 4: Logistic Results for Performance appraisal and customers satisfaction

\begin{tabular}{|c|c|c|c|c|}
\hline \multicolumn{5}{|c|}{ Model Fitting Information } \\
\hline Model & $-2 \quad \log$ & Chi- & Df & Sig. \\
\hline Intercept Only & $\begin{array}{l}\text { Likelihood } \\
75.514\end{array}$ & Square & & \\
\hline Final & 67.350 & 8.163 & 8 & 0.418 \\
\hline \multicolumn{5}{|c|}{ Goodness-of-Fit } \\
\hline & Chi-Square & df & Sig. & \\
\hline Pearson & 46.505 & 60 & 0.899 & \\
\hline Deviance & 47.778 & 60 & 0.873 & \\
\hline \multicolumn{5}{|c|}{ Pseudo R-Square } \\
\hline Cox and Snell & 0.181 & & & \\
\hline Nagelkerke & 0.195 & & & \\
\hline McFadden & 0.076 & & & \\
\hline \multicolumn{5}{|c|}{ Test of Parallel Linesa } \\
\hline Model & $\begin{array}{l}-2 \log \\
\text { Likelihood }\end{array}$ & $\begin{array}{l}\text { Chi- } \\
\text { Square }\end{array}$ & df & Sig. \\
\hline
\end{tabular}


Null Hypothesis

General

$39.422 b$

$27.928 \mathrm{c}$

24

0.263

\section{Explanatory variables associated with high level of customers satisfaction}

$\begin{array}{llc}\text { Item name } & \begin{array}{l}\text { Regression } \\ \text { coefficient }\end{array} & \text { p-value } \\ \begin{array}{l}\text { My appraiser helps me to understand the process used } \\ \text { to evaluate and rate my Performance }\end{array} & 0.007 \\ \begin{array}{l}\text { The performance appraisal review discussion is the } \\ \text { only time I get feedback about my performance }\end{array} & 0.575 \\ \begin{array}{l}\text { Employees are provided with feedbacks to help } \\ \text { improve their performance }\end{array} & 0.401 & 0.471 \\ \end{array}$

The model fitting information show the p-value was 0.419 indicating that there is no significant reduction in the chi-square statistics $(\mathrm{p}>$.005). The chi-square statistic (8.163) indicates that the model does not give a significant improvement over the baseline intercept-only model, implying that the model does not give better predictions than just guessing based on the marginal probabilities for the outcome categories.

The Goodness-of-Fit, which contains Pearson's chi-square statistic for the model and chi-square statistic based on the deviance for testing inconsistencies of observed data with the fitted model, shows that these statistics not significant. However, they are large enough to conclude that the data and the model predictions are similar. So, the model is a good one. The
Nagelkerke $\mathrm{R}^{2}(0.195)$ indicates the model can account for $19.50 \%$ of the variance in service delivery. The test of parallel lines accepts the null hypothesis of the assumption that across response categories". So, the model fits the data well since the observed significant level is large.

These results show that :my appraiser helps me to understand the process used to evaluate and rate my Performance" ( $p$-value = 0.007)was significant with customers satisfaction while "the performance appraisal review discussion is the only time I get feedback about my performance $(\mathrm{p}$-value $=0.170)$, "employees are provided with feedbacks to help improve their performance" $(\mathrm{p}$-value $=0.471)$ are not significant with customers satisfaction.

Table 5: Logistic Results for Performance appraisal and Employee commitment

\begin{tabular}{|c|c|c|c|c|}
\hline \multicolumn{5}{|c|}{ Model Fitting Information } \\
\hline Model & \multirow{2}{*}{ Likelihood } & \multirow{2}{*}{$\begin{array}{l}\text { Chi- } \\
\text { Square }\end{array}$} & \multirow[t]{2}{*}{ df } & \multirow[t]{2}{*}{ Sig. } \\
\hline Intercept Only & & & & \\
\hline Final & 63.990 & 6.273 & 8 & 0.617 \\
\hline \multicolumn{5}{|l|}{ Goodness-of-Fit } \\
\hline & Chi-Square & Df & Sig. & \\
\hline Pearson & 41.329 & 60 & 0.969 & \\
\hline Deviance & 41.627 & 60 & 0.966 & \\
\hline \multicolumn{5}{|c|}{ Pseudo R-Square } \\
\hline Cox and Snell & 0.142 & & & \\
\hline Nagelkerke & 0.152 & & & \\
\hline McFadden & 0.057 & & & \\
\hline \multicolumn{5}{|c|}{ Test of Parallel Linesa } \\
\hline Model & $-2 \quad \log$ & Chi- & df & Sig. \\
\hline Null Hypothesis & $\begin{array}{l}\text { Likelihood } \\
63.990\end{array}$ & Square & & \\
\hline General & $41.548 b$ & $22.442 \mathrm{c}$ & 24 & 0.553 \\
\hline
\end{tabular}

Explanatory variables associated with high level of Employee commitment 


$\begin{array}{llc}\text { Item name } & \begin{array}{l}\text { Regression } \\ \text { coefficient }\end{array} & \text { p-value } \\ \begin{array}{l}\text { My appraiser helps me to understand the process used to } \\ \text { evaluate and rate my Performance }\end{array} & 2.189 & 0.001 \\ \begin{array}{l}\text { The performance appraisal review discussion is the only } \\ \text { time I get feedback about my performance }\end{array} & 0.066 & 0.870 \\ \begin{array}{l}\text { Employees are provided with feedbacks to help improve } \\ \text { The }\end{array} & 0.383 & 0.48\end{array}$

The model fitting information show the p-value was 0.617 indicating that there is no significant reduction in the chisquare statistics (p>.005). The chi-square statistic (6.273) indicates that the model does not give a significant improvement over the baseline intercept-only model, implying that the model does not give better predictions than just guessing based on the marginal probabilities for the outcome categories.

The Goodness-of-Fit, which contains Pearson's chi-square statistic for the model and chi-square statistic based on the deviance for testing inconsistencies of observed data with the fitted model, shows that these statistics not significant. However, they are large enough to conclude that the data and the model predictions are similar. So, the model is a good one. The
Nagelkerke $\mathrm{R}^{2}(0.152)$ indicates the model can account for $15.20 \%$ of the variance in service delivery. The test of parallel lines accepts the null hypothesis of the assumption that across response categories". So, the model fits the data well since the observed significant level is large.

These results show that :my appraiser helps me to understand the process used to evaluate and rate my Performance" ( $p$-value = 0.001) was significant with employee commitment.while "the performance appraisal review discussion is the only time I get feedback about my performance $(\mathrm{p}$-value $=0.870)$, "employees are provided with feedbacks to help improve their performance" $(\mathrm{p}$-value $=0.480)$ are not significant with employee commitment.

Table 6: Logistic Results for Performance appraisal and Employees promotion

\begin{tabular}{|c|c|c|c|c|}
\hline \multicolumn{5}{|c|}{ Model Fitting Information } \\
\hline Model & $-2 \quad \log$ & Chi- & df & Sig. \\
\hline Intercept Only & $\begin{array}{l}\text { Likelihood } \\
68.694\end{array}$ & Square & & \\
\hline Final & 56.643 & 12.050 & 8 & 0.149 \\
\hline \multicolumn{5}{|l|}{ Goodness-of-Fit } \\
\hline & Chi-Square & df & Sig. & \\
\hline Pearson & 30.169 & 60 & 1.000 & \\
\hline Deviance & 34.045 & 60 & 0.997 & \\
\hline \multicolumn{5}{|l|}{ Pseudo R-Square } \\
\hline Cox and Snell & 0.255 & & & \\
\hline Nagelkerke & 0.274 & & & \\
\hline McFadden & 0.110 & & & \\
\hline \multicolumn{5}{|c|}{ Test of Parallel Linesa } \\
\hline Model & $\begin{array}{l}-2 \quad \log \\
\text { Likelihood }\end{array}$ & $\begin{array}{l}\text { Chi- } \\
\text { Square }\end{array}$ & df & Sig. \\
\hline Null Hypothesis & 56.643 & & & \\
\hline General & $41.364 b$ & $15.280 \mathrm{c}$ & 24 & 0.912 \\
\hline
\end{tabular}

Explanatory variables associated with high level of Employees promotion 


$\begin{array}{lll}\text { Item name } & \begin{array}{l}\text { Regression } \\ \text { coefficient }\end{array} & \text { p-value } \\ \begin{array}{l}\text { My appraiser helps me to understand the } \\ \text { process used to evaluate and rate my }\end{array} & 0.708 & \\ \begin{array}{l}\text { Performance } \\ \text { The performance appraisal review }\end{array} & 0.000 \\ \begin{array}{l}\text { discussion is the only time I get } \\ \text { feedback about my performance }\end{array} & \\ \begin{array}{l}\text { Employees are provided with feedbacks } \\ \text { to help improve their performance }\end{array} & & 0.046 \\ \end{array}$

The model fitting information show the p-value was 0.149 indicating that there is no significant reduction in the chi-square statistics ( $p>.005)$. The chi-square statistic (12.050) indicates that the model gives a moderate significant improvement over the baseline intercept-only model, implying that the model gives better predictions than just guessing based on the marginal probabilities for the outcome categories.

The Goodness-of-Fit, which contains Pearson's chi-square statistic for the model and chi-square statistic based on the deviance for testing inconsistencies of observed data with the fitted model, shows that these statistics not significant. However, they are large enough to conclude that the data and the model predictions are similar. So, the model is a good one. The
Nagelkerke $\mathrm{R}^{2}(0.274)$ indicates the model can account for $27.40 \%$ of the variance in service delivery. The test of parallel lines accepts the null hypothesis of the assumption that across response categories". So, the model fits the data very well since the observed significant level is large.

These results show that :"my appraiser helps me to understand the process used to evaluate and rate my Performance" (p-value $=0.000)$, "the performance appraisal review discussion is the only time I get feedback about my performance ( $\mathrm{p}$-value = 0.039), “employees are provided with feedbacks to help improve their performance" $(\mathrm{p}$-value $=0.046)$ are significant with employees promotion.

\section{Table 7: Logistic Results for Performance appraisal and Performance contracting}

\begin{tabular}{|c|c|c|c|c|}
\hline \multicolumn{5}{|l|}{ Model Fitting Information } \\
\hline Model & $\begin{array}{l}-2 \log \\
\text { Likelihood }\end{array}$ & $\begin{array}{l}\text { Chi- } \\
\text { Square }\end{array}$ & df & Sig. \\
\hline Intercept Only & 70.655 & & & \\
\hline Final & 58.820 & 11.835 & 8 & 0.159 \\
\hline \multicolumn{5}{|l|}{ Goodness-of-Fit } \\
\hline & Chi-Square & df & Sig. & \\
\hline Pearson & 32.966 & 60 & 0.998 & \\
\hline Deviance & 36.458 & 60 & 0.993 & \\
\hline \multicolumn{5}{|l|}{ Pseudo R-Square } \\
\hline Cox and Snell & 0.251 & & & \\
\hline Nagelkerke & 0.269 & & & \\
\hline McFadden & 0.107 & & & \\
\hline \multicolumn{5}{|l|}{ Test of Parallel Linesa } \\
\hline Model & $\begin{array}{l}-2 \log \\
\text { Likelihood }\end{array}$ & $\begin{array}{l}\text { Chi- } \\
\text { Square }\end{array}$ & $\mathrm{df}$ & Sig. \\
\hline Null Hypothesis & 58.820 & & & \\
\hline General & $118.528 b$ & c & 24 & \\
\hline \multicolumn{5}{|c|}{ Explanatory variables associated with high level of Performance contracting } \\
\hline Item name & $\begin{array}{l}\text { Regression } \\
\text { coefficient }\end{array}$ & p-value & & \\
\hline $\begin{array}{l}\text { My appraiser helps me to understand the process used to evaluate and } \\
\text { rate my Performance }\end{array}$ & 2.575 & 0.001 & & \\
\hline
\end{tabular}


The performance appraisal review discussion is the only time I get 0.031 feedback about my performance

Employees are provided with feedbacks to help improve their 0.722 performance
0.938

0.193
The model fitting information show the p-value was 0.15 indicating that there is no significant reduction in the chi-square statistics ( $p>005)$. The chi-square statistic (11.835) indicates that the model gives a moderate improvement over the baseline intercept-only model, implying that the model gives a better prediction than just guessing based on the marginal probabilities for the outcome categories.

The Goodness-of-Fit, which contains Pearson's chi-square statistic for the model and chi-square statistic based on the deviance for testing inconsistencies of observed data with the fitted model, shows that these statistics not significant. However, they are large enough to conclude that the data and the model predictions are similar. So, the model is a good one. The Nagelkerke $R^{2}(0.269)$ indicates the model can account for $26.90 \%$ of the variance in service delivery. The test of parallel lines accepts the null hypothesis of the assumption that across response categories". So, the model fits the data very well since the observed significant level is large.

These results show that :my appraiser helps me to understand the process used to evaluate and rate my performance" $(\mathrm{p}$-value $=$ 0.001 ) was significant with performance contracting while "the performance appraisal review discussion is the only time I get feedback about my performance ( $\mathrm{p}$-value $=0.938$ ), "employees are provided with feedbacks to help improve their performance" ( $\mathrm{p}$-value $=0.193)$ are not significant with Performance contracting.

According to these results, while all other relationship were significant;

a. my appraiser helps me to understand the process used to evaluate and rate my Performance" $(p$-value $=0.007)$ was significant with customers satisfaction

b. my appraiser helps me to understand the process used to evaluate and rate my Performance" $(p$-value $=0.001)$ was significant with employee commitment

c. my appraiser helps me to understand the process used to evaluate and rate my Performance" $(p$-value $=0.000)$, "the performance appraisal review discussion is the only time I get feedback about my performance ( $\mathrm{p}$-value = 0.039 ), "employees are provided with feedbacks to help improve their performance" $(\mathrm{p}$-value $=0.046)$ are significant with employees promotion

d. my appraiser helps me to understand the process used to evaluate and rate my performance" $(p$-value $=0.001)$ was significant with performance contracting

\section{CONCLUSIONS AND RECOMMENDATIONS}

\section{A Conclusion}

It was found that performance appraisal has relationship with employee performance among insurance firms in Kenya. It was further found that there is very high level of goal setting at every performance appraisal among insurance firms in Kenya where these companies set goals at every performance appraisal. The appraisers help employees understand the process used to evaluate and rate their performance while the performance review discussion is the only time the companies get feedback about employee performance. the study found that the employees are provided with feedback to help them improve their performance. notably, there is high performance appraisal among insurance firms in Kenya which spurs the employee performance of these institutions. The study concludes that there is effect of performance appraisal on employee performance among insurance firms in Kenya. The performance appraisal is necessary for helping employees understand the process used to evaluate and rate their performance, assisting the firm to get feedback about employee performance and providing employees with feedback which helps employee improve their performance.

\section{RECOMMENDATION}

The study made related policy recommendation as informed by the findings. Firstly, the study recommends that insurance firms in Kenya in collaboration with the IRA should structure and review their performance appraisal policy to include their support employee (low level staff) through representatives into the performance contacting team. These representatives are vital for informing the performance contacting team on issues bedeviling the employees as it also makes the employees clearly understand the evaluation process. Inclusion of the se of employees will also release the tension that builds between the different levels of employees in organizations and hence create conducive performance appraisal process.

\section{REFERENCES}

[1] Aguinis\& Herman. (2009). Performance Management. 2nd (Ed). Dorling Kindersley India Pvt. Ltd.

[2] Armstrong, M. A. (2005). Handbook of human resource management practice. New Delhi: Kogan Page India.

[3] Aronson, et al (2005). Social psychology, 7th ed. Upper Saddle River, NJ Pearson Education, Inc.

[4] Banjoko, S, N. (2006). Managing Corporate Reward System. Ibadan, Purmark Nigeria Limited, Education Publishers.

[5] Cheche, G.\&Muathe.A., (2014). A Critical Review of Literature on Performance Contracting. Global Journal of Commerce \& Management Perspective (GJCMP). 3(6), 65-70.

[6] Cromption R \&Lyonette, C. (2005). The new Gender Essentialism-domestic and Family "Choices" and their Relation to Attitude. The British Journal of Sociology, 56(4):601-20.

[7] Gesare, D., Elegwa, M. \& Kwasira, J. (2016). Reward and Recognition Programmes and their influence on service delivery in state corporations in Kenya. International Journal of Education and Resaerch.

[8] GOK, (2003), Economic Recovery Strategy for Wealth and Employment Creation. Nairobi: Government Printer.

[9] GOK, (2005). Ministry Human Resources Development Strategy. Nairobi Government Printer. 55

[10] GoK, (2010). Performance Contracting Department report on evaluation of the performance of public agencies for the financial year 2008/2009.Nairobi: Government Printer.

[11] Gupta, S. K. \& Rangi, R. (2014). Research methodology. Methods, tools and techniques (4th ed.). New Delhi: Kalyan Publishers. 
[12] Jiang, Y., \&Seidmann, A., (2014) Capacity planning and performance contracting for service facilities. Decision Support Systems, 5, 831-42.

[13] Kemboi, A., (2015). Performance Contracting as a Strategy for Enhanced Employee Commitment: A Case of the Vocational Training Centre Sikri, Kenya. International Journal of Business and Social Research, 5(12), 56-67.

[14] Kiboi, W. (2006). Management perception of performance contracting in state corporations. An unpublished MBA projects. University of Nairobi

[15] Kirkpatrick, D, L. (2006). Training and Performance Appraisal - Are they Related? Improving Employee Performance Through Appraisal and Coaching.

[16] Kobia, M. \& Mohammed, N. (2006). The Kenyan Experience with Performance Contracting: Discussion Paper, 28th AAPAM Annual RoundTable Conference, Arusha, Tanzania.

[17] Korir, P.K., (2006) "The impact of performance contracting in state corporations", The 56 case of East African Portland Cement Company limited, Unpublished MBA Project. University of Nairobi.

[18] Kothari, C. R. (2012). Research Methodology: Methods and Techniques. (2nd Ed), Nairobi, Kenya: New Age International Publishers.

[19] Kuvaas, B. (2006). Different Relationships between Perceptions of Developmental Performance Appraisal and Work Performance. Personnel Rewiew, 36(3), 378-398.

[20] Lambert, C. (2009). Field Sales Performance Appraisal. (3rd Ed), John Wley\& Sons, New Yolk.

[21] Maina, J. M. (2015). Effect of performance management system on employee performance: A study of food and agriculture organization (Masters Research Project, United States International University Africa, Nairobi, Kenya).

[22] Mathias, R.\& Jackson, J.(2011).Human resources management (5th edition )south western,

[23] Mbuthia, R., Ngari, J., \& Mwanhi, B. (2014). Effectiveness of Performance Contracting: In Public Institutions in Nakuru County-A Case Study of the Provincial General Hospital. LAP LAMBERT Academic Publishing.

[24] Muthaura, F. (2003). Presentation on Performance Contracts, retrieved on July $11, \quad 2011 \quad$ from www.unpan.org/innovmed/documents/Vienna07/28June07/03_Kenya.ppt

[25] Ojo, O. (2009). Impact assessment of corporate culture on employee job: Journal of Business intelligence, 2/2, 389-37. [13].

[26] Omondi, J.D., (2015), A Study on Effects of Performance Contracting Implementation on Service Deliveryat Kenya Ports Authority, 4(6), 34-45.

[27] Osabiya, B, J. (2014). Effectiveness of Performance Appraisal as a Tool to Measure Employee Productivity in Organizations, Journal of Public administration and Governance, 4(4), 135-148.
[28] Parijat, P., \& Bagga, S., (2014). Victor Vroom's Expectancy Theory of Motivation-An Evaluation. International Research Journal of Business and Management - IRJBM.

[29] Republic of Kenya. (2009). Economic Survey. Nairobi, Government Press.

[30] Roseman, I.J., Smith, C.A., \&, . (2001). Appraisal theory: overview, assumptions, varieties, controversies. New York, NY: Oxford University Press, USA.

[31] Salaman, et al, (2005). Strategic Human Resource Management: Theory and Practice, 2nd (Ed). Sage Publications Ltd.

[32] Saunders et al. (2009). Research methods for business students. (5th Edition). London: Prentice Hall.

[33] Scherer, K. R. (2001). Appraisal Considered as a Process of Multilevel Sequential Checking. In K. R. Scherer, A. Schorr \& T. Johnstone (Eds.), Appraisal

[34] Sekaran, U. \& Bougie, R. (2010). Research Methods for Business: A Skill Building Approach. UK: John Wiley \& Sons.

[35] Smith A., \& Kirby D. (2009). Putting appraisal in context: Toward a relational model of appraisal and emotion. Cognition and Emotion, 23 (7), 1352-1372.

[36] Tonui, E. K., (2010) Effects of Performance Targets on Employee Delivery in Public Institutions in Kenya: A Case of National Social Security Fund

[37] Tourish, D. (2006). In the Appraisal Interview Reappraised. London. Edited by R.G. University.

[38] Verduyn, P. Mechelen v. (2011). “The Relationship Between Event Processing and the Duration of Emotional Experience." Emotion. Vol. 11(1), 20-28.

[39] Weinert,A.B (2001)psychology of career development encyclopedia of social \&behaviouralsciences, elerview science.1471-1476

[40] White paper no 25, (2005-2006): Competence, Opportunities and Meaning. Edited by T.r.h.c. ministry. Government Stoltenberg;

[41] Zikmund, W. G. (2010). Business Research Methods. (7Ed.), New Delhi, South Western.

\section{AUTHORS}

First Author - Dr.Tabitha Murerwa

Second Author - Dr. Susan Nzioki

Third Author - Dr.Wilson Muema 